\title{
An Ecto-ATPase Activity Present in Leishmania tropica Stimulated by Dextran Sulfate
}

\author{
Carlos Eduardo Peres-Sampaio, Simone Thorp Palumbo and José Roberto \\ Meyer-Fernandes* \\ Departamento de Bioquímica Médica, Instituto de Ciências Biomédicas, Universidade Fed- \\ eral do Rio de Janeiro, CCS, Bloco H, Cidade Universitária, Ilha do Fundão, 21541-590, \\ Rio de Janeiro, RJ, Brazil. Fax: +55-21-270-8647. E-mail: meyer@bioqmed.ufrj.br \\ *Author for correspondence and reprint requests \\ Z. Naturforsch. 56c, 820-825 (2001); received April 11/May 30, 2001
}

Leishmania tropica, Ecto-ATPase, Sulfated Polysaccharides

In this study we report the effects of sulfated polysaccharides on the ecto-ATPase activity of intact cells of Leishmania tropica. Increasing concentrations of dextran sulfate stimulated progressively the ecto-ATPase activity, but did not modify other ecto-enzymes present on the surface of this parasite, such as 5'nucleotidase, 3'nucleotidase and a membrane-bound acid phosphatase activity. This stimulation was not observed when other sulfated polysaccharides such as chondroitin sulfates and heparin were tested. It depends on size and charge of the dextran sulfated molecule. When the cells were incubated in the presence of dextran sulfate $M r 8,000 ; 40,000$ and 500,000 the stimulation of the ecto-ATPase activity was $11 \%$; $23 \%$; and $63 \%$, respectively, and the stimulation was not observed when desulfated dextran $(\mathrm{Mr}$ 40,000) was used. The effects of dextran sulfate also depend on $\mathrm{pH}$ of the medium. At $\mathrm{pH} 7.5$, the stimulation was over $60 \%$, whereas at $\mathrm{pH} 8.5$ only $25 \%$. The effects of dextran sulfate 500,000 on the ecto-ATPase activity was totally abolished by spermidine and partially by putrescine, two polyamines synthesized and released by Leishmania.

\section{Introduction}

Infection with Leishmania, a parasitic protozoan, represents a major health problem in the tropics and subtropics, with $\sim 380000$ cases annually and 367 million people at risk of infection (Ashford et al., 1992). During their life cycle, the parasites undergo profound morphological changes. Leishmania parasites lead a digenetic life cycle, with the parasites migrating between insect vectors and mammalian hosts. The parasites exist in two forms, as extracellular flagellated promastigotes in the alimentary tract of the sand fly vector and as obligatory intracellular amastigote within the phagolysosome vacuoles of mammalian macrophages (Ashford et al., 1992). Once inside the phagolysosome, promastigotes transform into non-motile, non-flagellated amastigote (Ashford et al., 1992).

Cell-cell recognition and adherence are central processes to many fundamental areas of biology.

Abbreviations: $p$-NP, $p$-nitrophenol; $p$-NPP, $p$-nitrophenylphosphate; PPO, 2,5-diphenyloxazole; POPOP, 1,4bis[2-(5-phenyloxazoly)] benzene; Tris, Tris(hydroxymethyl)aminomethane.
Surface membrane interactions between parasites and their host cells are of critical importance for the parasite survival, from both immunological and physiological points of view (Martiny et al. 1996, 1999). Ecto-ATPases are integral membrane glycoproteins that exhibit divalent cation-dependent ATPase activity on the extracellular side of the plasma membrane. The identities and functions of ecto-ATPases are the subject of a recent review in which the nomenclature of "E-type ATPases" was proposed to describe these enzymes (Plesner, 1995). Their physiological role is still unknown. However, several hypotheses have been suggested, such as regulation of ectokinase substrate concentration (Plesner, 1995), involvement in signal transduction (Dubyak and El-Motassim, 1993), and involvement in cellular adhesion (Dzhandzhugazyan and Bock, 1993; Kirley, 1997).

Recently, we have shown that in Entamoeba histolytica, galactose stimulated a $\mathrm{Mg}^{2+}$-dependent ecto-ATPase involved in the virulence of this parasite (Barros et al., 2000). In this regard, it has been shown that a $46-\mathrm{kDa}$ lectin isolated from root extracts of legume Doliclos biflorus is a Nod factor binding protein as well as a nucleoside di- and tri- 
phosphate hydrolase stimulated by carbohydrate ligands (Etzler et al., 1999). Bacterial lipopolysacharide (LPS) is a potent and pleiotropic stimulus of immune cells, both in vitro and in vivo (Morrison and Ryan, 1987; Lynn and Golenbock, 1992). In vertebrate blood cells the biological responses to LPS involve the increase of adhesion capacity (Lynn and Golenbock, 1992), whereas in endothelial cells, LPS treatment modifies $\mathrm{pH}$ - and cationdependent ecto-ATPase activity, increasing the Mg-dependent ecto-ATPase activity (Kittel, 1992). Several studies have already demonstrated that sulfated polysaccharides interact with components of the plasma membrane of the parasite enhancing the process of invasion of the host cell. It has been shown the importance of glycosaminoglycans and glycosaminoglycan-binding proteins for the interactions between Leishmania donovani (Chakraborty and Das, 1988; Mukhopadhyay et al., 1989; Butcher et al., 1990, 1992) as well as Trypanosoma cruzi (Ortega-Barria and Pereira, 1991) and their mammalian target cells.

A previous report from our laboratory has shown a $\mathrm{Mg}^{2+}$-dependent ecto-ATPase present on the external surface of Leishmania tropica (MeyerFernandes et al., 1997). In this study we investigated the effects of sulfated polysaccharides on the ecto-ATPase activity of $L$. tropica.

\section{Material and Methods}

\section{Growth of Microorganisms}

L. tropica stock IOC-L 571, from a WHO collection, was provided by Dr. G. Grimaldi Jr. (Fundação Oswaldo Cruz, Rio de Janeiro, RJ, Brazil). The parasites were cultured as promastigotes in Schneider's Drosophila medium (GIBCO, Grand Island, NY), supplemented with $10 \%$ fetal bovine serum (GIBCO) at $24{ }^{\circ} \mathrm{C}$ (Lopes and McMahonPratt, 1989), and were harvested at the stationary phase of growth. Five days after inoculation, cells were collected by centrifugation, washed twice, and kept in $50 \mathrm{~mm}$ Tris-maleate, $\mathrm{pH} 7.5,20 \mathrm{~mm}$ $\mathrm{KCl}, 100 \mathrm{~mm}$ sucrose, and $20 \mathrm{~mm}$ glucose. Cellular viability was assessed, before and after incubation, by mobility and Trypan blue dye exclusion (Dutra et al., 2000). The viability was not affected under the conditions employed here. Protein concentration was determined by the method of Lowry et al. (1951) using bovine serum albumin as standard.

\section{Ecto-ATPase activity measurements}

Intact cells were incubated for $1 \mathrm{~h}$ at $30^{\circ} \mathrm{C}$ with gentle shacking (40 oscillations/min) in $0.5 \mathrm{ml}$ of a mixture containing, unless otherwise specified, $50 \mathrm{~mm}$ Tris-maleate, $\mathrm{pH} 7.5,5 \mathrm{~mm}$ ATP, $5 \mathrm{~mm}$ $\mathrm{MgCl}_{2}$, and $1 \mathrm{mg} / \mathrm{ml}$ of protein which corresponds to $2.2 \times 10^{8}$ cells $/ \mathrm{ml}$. The ATPase activity was determined by measuring the hydrolysis of $\left[\gamma^{32} \mathrm{P}\right]$ ATP $\left(10^{4} \mathrm{~Bq} / \mathrm{nmol}\right.$ ATP) (Bernardes et al., 1997). The experiments were started by the addition of living cells and terminated with $1 \mathrm{ml}$ of a cold mixture containing $0.2 \mathrm{~g}$ charcoal in $0.1 \mathrm{M} \mathrm{HCl}$. The tubes were then centrifuged at $1500 \times g$ for $20 \mathrm{~min}$ at $4{ }^{\circ} \mathrm{C}$, then $400 \mu \mathrm{l}$ of the supernatant were added to $9 \mathrm{ml}$ of scintillation liquid ( $2 \mathrm{~g}$ PPO, $1 \mathrm{~g}$ POPOP in 1 liter toluene) and counted in a liquid scintillation counter. The ATPase activity was calculated by subtracting the nonspecific ATP hydrolysis measured in the absence of cells. ATP hydrolysis was linear with time under the assay conditions used and was proportional to the cell density. In the experiments in which other nucleotides (5' AMP and 3' AMP) were used, the hydrolytic activity measured under the same conditions described above was assayed spectrophotometrically by measuring the release of $\mathrm{P}_{\mathrm{i}}$ from the nucleotides (Lowry and Lopez, 1946). The values obtained for ATPase activities measured using both methods (colorimetric and radioactive) were exactly the same.

\section{Phosphatase activity measurement}

The ecto- $p$-nitropenylphosphatase activity was determined in the same medium for ATP hydrolysis except that ATP was replaced by $5 \mathrm{~mm} p$-nitrophenylphosphatase ( $p$-NPP). The reaction was terminated with $1 \mathrm{ml}$ of $1 \mathrm{~N} \mathrm{NaOH}$. The released $p$ nitrofenol ( $p$-NP) was determined spectrophotometrically at $425 \mathrm{~nm}$ using an extinction coefficient of $14.3 \times 10^{3} \mathrm{M}^{-1} . \mathrm{cm}^{-1}$ (Dutra et al., 1998).

\section{Reagents}

All reagents were purchased from Merck S. A. (São Paulo, S. P.) or Sigma Chemical Co. (St. Louis, MO). $\left[\gamma_{-}{ }^{32} \mathrm{P}\right]$ ATP was prepared as described by Glynn and Chappel (1946). Distilled water deionized by the MilliQ system of resins 
(Millipore Corp., Bedford, MA) was used in the preparation of all solutions.

\section{Statistical analysis}

All experiments were performed in triplicate, with similar results obtained at least three separate cell suspensions. Statistical significance was determined by Student's $t$ test. Significance was considered as $P<0.05$.

\section{Results and Discussion}

In invertebrate blood cells the biological responses to lipopolysacharide involve the increase of aggregation and phagocytosis (Lanz-Mendoza et al., 1996), as well as the increase on ecto-ATPase activity (Meyer-Fernandes et al., 2000). Sulfated polysaccharides are found at the extracellular space of different animal tissues, but their physiological role is poorly understood (Kjel1èn and Lindahl, 1991; Hardingham and Fosang, 1992; Yanagishita, 1993). These molecules are able to bind at the surface of Leishmania donovani and Trypanosoma cruzi enhancing the invasion of the parasite to the host cells (Chakraborty and Das, 1988; Mukhopadhyay et al., 1989; Butcher et al., 1990, 1992; Ortega-Barria and Pereira, 1991). The objective of this work was to study the effect of sulfated polysaccharides on the $\mathrm{Mg}^{2+}$-dependent ecto-ATPase of Leishmania tropica.

Fig. 1 shows that dextran sulfate $M r 500,000$ stimulated the $\mathrm{Mg}^{2+}$-dependent ecto-ATPase activity in a dose-dependent manner (open circles). This effect was not observed when dextran sulfate was replaced by other sulfated polysaccharides, such as heparin (closed circles), Condroitin 4-sulfate (open squares) and Condroitin 6-sulfate (closed squares). This effect is dependent on size and charge of the polysaccharide (Fig. 2A). Other sulfated dextrans with lower molecular weight and desulfated dextran were less efficient to promote stimulation of ecto-ATPase activity. When the cells were incubated at $\mathrm{pH} 7.5$ in the presence of dextran sulfate $\mathrm{Mr} 500,000$ (open circles); $\mathrm{Mr}$ 40,000 (closed circles) and $M r$ 8,000 (open squares) the stimulation of ecto-ATPase activity was $63 \% ; 23 \%$; and $11 \%$ respectively. This stimulation was not observed when desulfated dextran $\operatorname{Mr}$ 40,000 (Fig. 2A, closed squares) was added to the assay media. The degree of the stimulation

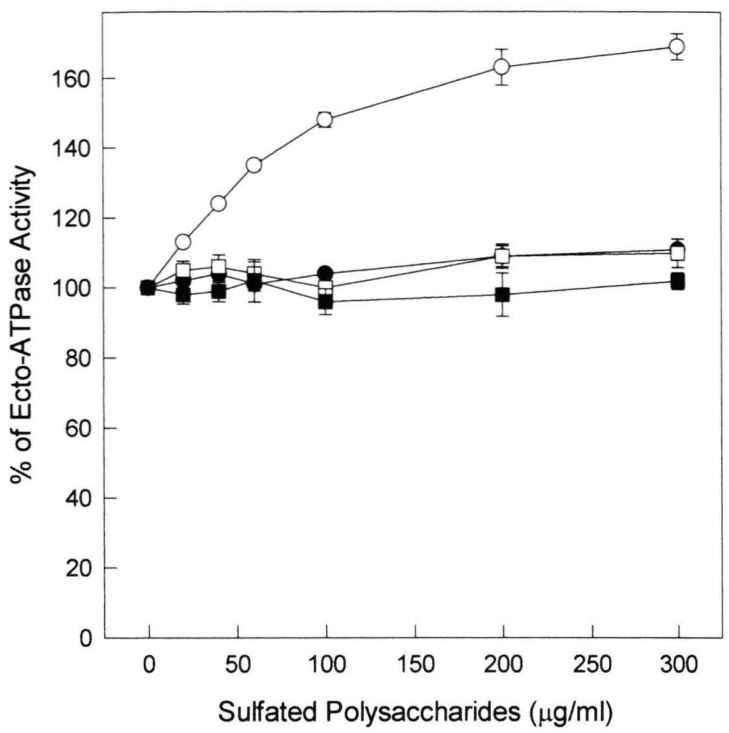

Fig. 1. Effects of increasing concentration of different sulfated polysaccharides on ecto-ATPase of living cells of Leishmania tropica. Cells were incubated for $1 \mathrm{~h}$ at $30^{\circ} \mathrm{C}$ in a reaction medium (final volume $0.5 \mathrm{ml}$ ) containing $30 \mathrm{~mm}$ Tris-maleate buffer, $\mathrm{pH} 7.5,5 \mathrm{~mm}$ Tris-ATP $\left[\gamma^{32} \mathrm{P}\right]$ ATP (specific activity about $10^{4} \mathrm{~Bq} / \mathrm{nmol}$ ATP), $5 \mathrm{mM} \mathrm{MgCl}_{2}, 1 \mathrm{mg} / \mathrm{ml}$ of protein which corresponds to $2.2 \times 10^{8}$ cells $/ \mathrm{ml}$ with the concentrations of sulfated polysaccharides dextran sulfate $M r 500,000(\circ)$, heparin $(\bullet)$, condroitin 4-sulfate $(\square)$ and chondroitin 6-sulfate (ש) shown on the abscissa. The ATP hydrolysis (403.1 \pm $31.3 \mathrm{nmol} / \mathrm{mg}$ protein $\times \mathrm{h}$ ) was taken as $100 \%$. The standard errors were calculated from the absolute activity values of three experiments with different cell suspensions and converted to percentage of the control value.

promoted by dextran sulfate also depended on the $\mathrm{pH}$ of the medium. As shown in Figure 2B, at $\mathrm{pH} 7.5$, the stimulation was more than $65 \%$, whereas at $\mathrm{pH} 8.5$ the stimulation was only $25 \%$. These results suggest that protonation or deprotonation of side-chain groups could be involved in the reversible binding of dextran sulfate to the ecto-ATPase.

Recent reports have shown that sulfated polysaccharides including dextran sulfate, modulate different intracellular ATPases. These polysaccharides are able to uncouple $\mathrm{Ca}^{+2}$-ATPases from sarcoplasmic reticulum, blood platelets and brain microsomes (De Meis and Suzano,1994; Rocha et al., 1996, 1998), and these effects are antagonized by polyamines (De Meis and Suzano,1994). Polyamines, particularly spermidine, spermine and putrescine, are ubiquitous components of eukaryote 


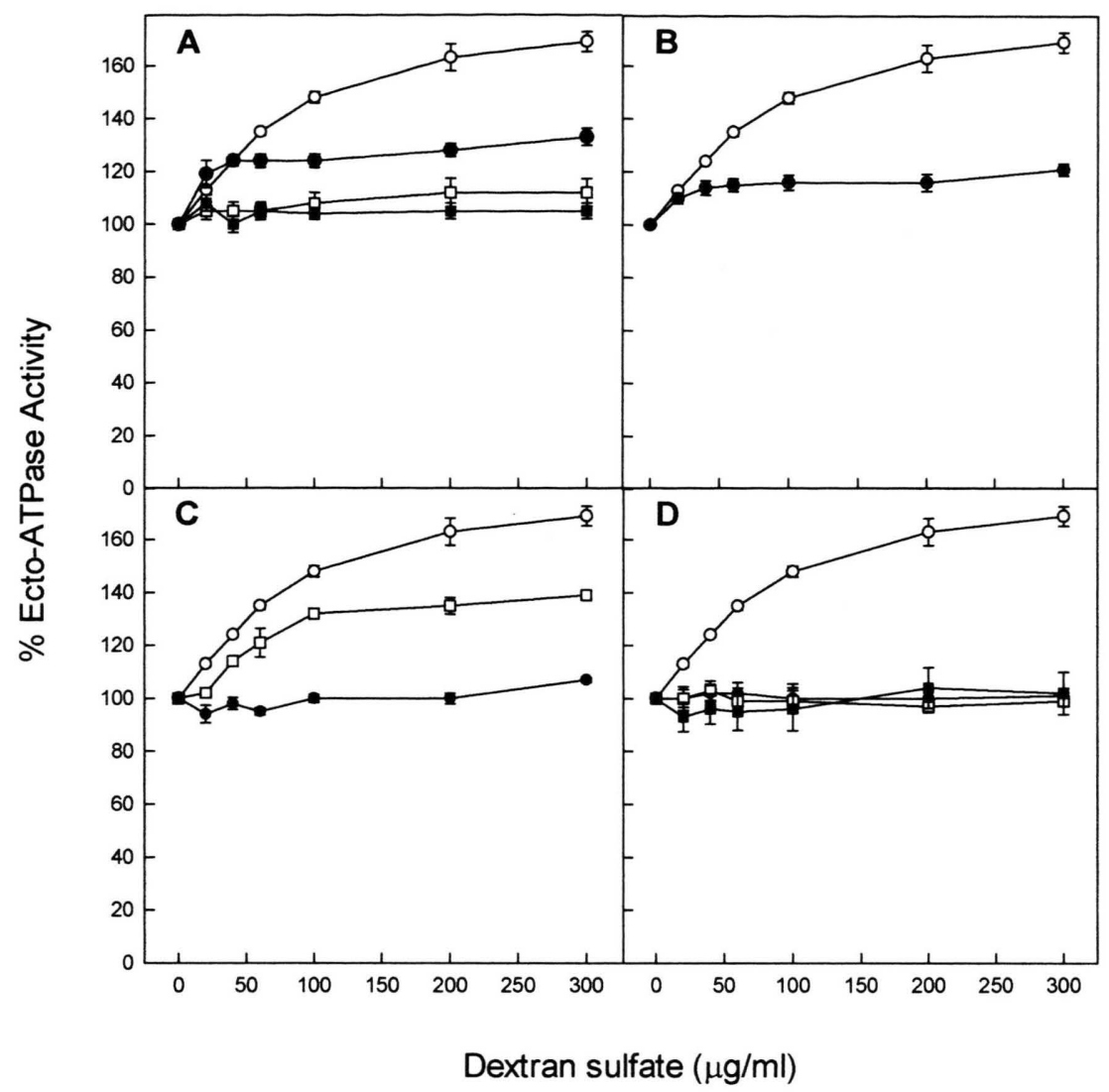

Fig. 2A. Effects of increasing concentrations of dextran sulfate on ecto-ATPase of living cells of Leishmania tropica. Cells were incubated for $1 \mathrm{~h}$ at $30^{\circ} \mathrm{C}$ in the same reaction medium (final volume $0.5 \mathrm{ml}$ ) described in Fig. 1 , with concentrations of dextran sulfate $M r 500,000(0), M r 40,000(\bullet), M r 8,000(\square)$ and dextran desulfated $M r 40,000(\boldsymbol{\square})$ indicated on the abscissa. The ATP hydrolysis $(396.4 \pm 21.3 \mathrm{nmol} / \mathrm{mg}$ protein $\times \mathrm{h})$ was taken as $100 \%$. The standard errors were calculated from the absolute activity values of three experiments with different cell suspensions and converted to percentage of the control value.

B. $\mathrm{pH}$ dependence of the stimulation of ecto-ATPase activity of living cells of Leishmania tropica promoted by dextran sulfate $M r 500,000$. Cells were incubated for $1 \mathrm{~h}$ at $30^{\circ} \mathrm{C}$ in the same reaction medium (final volume $0.5 \mathrm{ml}$ ) described in Figure 1 with the concentrations of dextran sulfate $\mathrm{Mr}$ 500,000 indicated on the abscissa at $\mathrm{pH} 7.5$ ( 0 ) or $\mathrm{pH} 8.5(\bullet) .100 \%$ activity corresponds to $399.2 \pm 28.3 \mathrm{nmol} / \mathrm{mg}$ protein $\times \mathrm{h}$ at $\mathrm{pH} 7.5 \mathrm{and} 723.9 \pm 54.7 \mathrm{nmol} / \mathrm{mg}$ protein $\times \mathrm{h}$ at $\mathrm{pH}$ 8.5. The standard errors were calculated from the absolute activity values measured at $\mathrm{pH} 7.5$ or $\mathrm{pH} 8.5$ of three experiments with different cell suspensions and converted to percentage of the control value.

C. Antagonism effects of polyamines on the stimulation of ecto-ATPase activity of living cells of Leishmania tropica promoted by dextran sulfate $\mathrm{Mr} 500,000$. Cells were incubated for $1 \mathrm{~h}$ at $30^{\circ} \mathrm{C}$ in the same reaction medium (final volume $0.5 \mathrm{ml}$ ) described in Fig. 1 with the concentrations of dextran sulfate $\mathrm{Mr} 500,000$ indicated on the abscissa, in the abscense $(0)$ or in the presence of $1 \mathrm{~mm}$ spermidine $(\bullet)$ or in the presence of $1 \mathrm{~mm}$ putrescine ( $\square$ ). The standard errors were calculated from the absolute activity values of three experiments with different cell suspensions and converted to percentage of the control value.

D. Effects of dextran sulfate $M r$ 500,000 on the ecto-enzymes (ATPase, 5'nucleotidase, 3'nucleotidase and phosphatase) activities of living cells of Leishmania tropica. Cells were incubated for $1 \mathrm{~h}$ at $30^{\circ} \mathrm{C}$ in the same reaction medium (final volume $0.5 \mathrm{ml}$ ) described in Figure 1, with $5 \mathrm{~mm}$ of each substrates ATP (O), 5' AMP (•), 3'AMP ( $\square$ ) and $p$ NPP ( $)$ with concentrations of dextran sulfate $M r 500,000$ indicated on the abscissa. $100 \%$ activity corresponds to $423.9 \pm 41.8 \mathrm{nmol} / \mathrm{mg}$ protein $\times$ h for ATPase activity; $123.6 \pm 10.8 \mathrm{nmol} / \mathrm{mg}$ protein $\times$ h for phosphatase activity; $110.3 \pm 5.53 \mathrm{nmol} / \mathrm{mg}$ protein $\times \mathrm{h}$ for $3^{\prime}$ nucleotidase activity and $12.25 \pm 0.41 \mathrm{nmol} / \mathrm{mg}$ protein $\times \mathrm{h}$ for 5 'nucleotidase activity. The standard errors were calculated from the absolute activity values of three experiments with different cell suspensions and converted to percentage of the control value. 
cells, including Leishmania (Yarlett, 1988; Basselin et al., 2000), and are essential for optimal cell proliferation and differentiation (Yarlett, 1988; Basselin et al., 2000). In this regard, it has been shown that ATP and other nucleotides stimulate the proliferation of different cell types, while their metabolism is controlled mainly by enzymes like ectoATPase, ecto-5'nucleotidase and ecto-phosphatases, which are believed to be ubiquitously present on the surface of many cell types (Gordon, 1986; Lemmens et al., 1996; Fernandes et al., 1997; Meyer-Fernandes et al., 1999). Figure 2C shows that the addition of $1 \mathrm{~mm}$ spermidine or putrescine did not have any effect on the ecto-ATPase activity, but was able to antagonize totally or partially, respectively, the stimulating effect promoted by dextran sulfate. These polyamines are synthesized and transported by Leishmania (Yarlett, 1988; Basselin et al., 2000) and could modulate the effects of extracellular components on this ecto-ATPase.

Protozoa of genus Leishmania have been shown to possess three other distinct phosphomonoesterase activities (acid phosphatase, 5'nucleotidase and 3'nucleotidase) all of which are also localized on the external surface of the plasma membrane

Ashford R. W., Desjeux P. and de Raadt P. (1992), Estimation of population at risk of infection and number of cases of Leishmaniasis. Parasitol. Today 8, 104-105.

Barros F. S., De Menezes L. F., Pinheiro, A. A. .S., Silva E. F., Lopes A. H. C. S., De Souza W. and Meyer-Fernandes J. R. (2000), Ectonucleotide diphosphohydrolase activities in Entamoeba histolytica. Arch. Biochem. Biophys. 375, 304-314.

Basselin M., Coombs G. H. and Barret M. P. (2000), Putrescine and spermidine transport in Leishmania. Mol. Biochem. Parasitol. 109, 37-46.

Bernardes C. F., Meyer-Fernandes J. R., Martins O. B., and Vercesi A. E. (1997), Inhibition of succinic dehydrogenase and $\mathrm{F}_{0} \mathrm{~F}_{1}$-ATPase synthase by $4,4^{\prime}$-diisothiocyanatostilbene-2,2'-disulfonic acid (DIDS). Z. Naturforsch. 52c, 799-806.

Butcher B. A., Shome K., Estes L. W., Choay J., Petitou M., Sie P. and Glew, R. H. (1990), Leishmania donovani: Cell surface heparin receptors of promastigotes are recruited from an internal pool after trypsinization. Exp. Parasitol. 71, 49-59.

Butcher B. A., Sklar L. A., Seamer L. C. and Glew R. H. (1992), Heparin enhances the interaction of infective Leishmania donovani promastigotes with mouse peritoneal macrophages. J. Immunol. 148, 2879-2886.
(Gottlieb and Dwyer, 1983; Dwyer and Gottlieb, 1984; Hassan and Coombs, 1987). Figure 2D, shows that $300 \mu \mathrm{g} / \mathrm{ml}$ dextran sulfate $M r 500,000$ stimulated the ecto-ATPase more than $60 \%$ of activity, but had no effect on the ecto-phosphatase, $3^{\prime}$-nucleotidase or 5 '-nucleotidase activities, showing that this effect promoted by dextran sulfate is specific for the ecto-ATPase present in this parasite. As it has been suggested that ecto-ATPases might be involved in cellular adhesion (Dzhandzhugazyan and Bock, 1993; Kirley, 1997; Barros et al., 2000; Meyer-Fernandes et al., 2000), it remains to be elucidated whether dextran sulfate may have an effect on the interaction between Leishmania tropica with their mammalian target cells.

\section{Acknowledgments}

We would like to acknowledge the excellent technical assistance of Fabiano Ferreira Esteves. This work was partially supported by grants from the Brazilian Agencies Conselho Nacional de Desenvolvimento Científico e Tecnológico ( $\mathrm{CNPq})$, Financiadora de Estudos e Projetos (FINEP), Fundação de Amparo à Pesquisa do Estado do Rio de Janeiro (FAPERJ) and Programa de Núcleos de Excelência (PRONEX, grant 0885).

Chakraborty P. and Das P. K. (1988), Role of mannose/ $\mathrm{N}$-acetylglucosamine receptors in blood clearance and cellular attachment of Leishmania donovani. Mol. Biochem. Parasitol. 28, 55-62.

De Meis L. and Suzano V. A. (1994), Uncoupling of muscle and blood platelets $\mathrm{Ca}^{+2}$ transport ATPases by heparin. J. Biol. Chem. 269, 14525-14529.

Dubyak G. R. and El-Motassim C. (1993), Signal transduction via $\mathrm{P}_{2 \times}$ purinergic receptors for extracellular ATP and other nucleotides. Am. J. Physiol 34, C577C606.

Dutra P. M. L., Rodrigues C. O., Jesus J. B., Lopes A. H. C. S., Souto-Padrón T. and Meyer-Fernandes J. R. (1998), A novel ecto-phosphatase activity of Herpetomonas muscarum muscarum inhibited by platelet activating factor. Biochem. Biophys. Res. Commun. 253, $164-169$.

Dutra P. M. L., Rodrigues C. O., Romeiro A., Grillo L. A. M., Dias F. A., Attias M., De Souza W., Lopes A. H. C. S. and Meyer-Fernandes J. R. (2000), Characterization of ectophosphatase activities in trypanosomatid parasites of plants. Phytopathology 90, 10321038.

Dwyer D. M. and Gottieb M. (1984), Surface membrane localization of $3^{\prime}$ and $5^{\prime}$-nucleotidase activities in 
Leishmania donovani promastigote. Mol. Biochem. Parasitol. 10, 139-150.

Dzhandzhugazyan K. and Bock E. (1993), Demonstration of $\left(\mathrm{Ca}^{+2}-\mathrm{Mg}^{2+}\right)$-ATPase activity of the neural cell adhesion molecule. FEBS Lett. 336, 279-283.

Etzler M. E. Kalsi G., Ewing N. N., Roberts N. J., Day R. B. and Murphy J. B. (1999), A nod factor binding lectin with apyrase activity from legume roots. Proc. Natl. Acad. Sci. USA 96, 5856-5861.

Fernandes E. C., Meyer-Fernandes J. R., Silva-Neto M. A. C. and Vercesi A. E. (1997), Trypanosoma brucei: ecto-phosphatase activity on the surface of intact procyclic forms. Z. Naturforsch. 52c, 351-358.

Glynn I. M. and Chappel J. B. (1964), A simple method for the preparation of ${ }^{32} \mathrm{P}$-labelled adenosine triphosphate of high specific activity. Biochem. J. 90, 147149.

Gordon J. L. (1986), Extracellular ATP: effects, sources and fate. Biochem. J. 233, 309-319.

Gottieb M. and Dwyer D. M. (1983), Evidence for distinct $5^{\prime}$ - and $3^{\prime}$-nucleotidase activities in the surface membrane fraction of Leishmania donovani promastigotes. Mol. Biochem. Parasitol. 7, 303-317.

Hardingham,T. E. and Fosang A. J. (1992), Proteoglycans: many forms and many functions. FASEB J. 6 , $861-870$.

Hassan H. F. and Coombs G. H. (1987), Phosphomonoesterases of Leishmania mexicana mexicana and others flagellates. Mol. Biochem. Parasitol. 23, 285296.

Kirley T. L. (1997), Complementary DNA cloning and sequencing of the chicken muscle ecto-ATPase. Homology with the lymphoid cell activation antigen CD39. J. Biol. Chem. 272, 1076-1081.

Kittel A. (1999), Lipopolysaccharide treatment modifies $\mathrm{pH}-$ and cation-dependent ecto-ATPase activity of endothelial cells. J. Histochem. Cytochem. 47, 393399.

Kjellén L. and Lindahl U. (1991), Proteoglycans: Structures and interactions. Annu. Rev. Biochem. 60, $443-475$.

Lanz-Mendoza H., Bettencourt R., Fabri M. and Faye I. (1996), Regulation of the insect immune response: the effect of hemolin on cellular immune mechanisms. Cell Immunol. 169, 47-54.

Lemmens R., Vanderfell L., Teuchy H. and Culic O. (1996), Regulation of proliferation of LLC-MK2 cells by nucleosides and nucleotides: the role of ecto-enzymes. Biochem. J. 316 (1996) 551-557.

Lopes A. H. C. S, and McMahon-Pratt D. (1989), Monoclonal antibodies specific for members of the genus Endotrypanum. J. Protozool. 36, 354-361.

Lowry O. H. and Lopez M. (1946), The determination of inorganic phosphate in the presence of labile phosphate esters. J. Biol. Chem. 162, 421-428.
Lowry O. H., Rosebrough N. J., Farr A. L. and Randall R. J. (1951), Protein measurement with the Folin phenol reagent. J. Biol. Chem. 193, 265-275.

Lynn W. A. and Golenbock D. T. (1992), Lipopolysaccharide antagonists. Immunol. Today 13, 271-276.

Martiny A., Vannier-Santos M. A., Borges V. M., MeyerFernandes J. R., Asseruy J., Cunha e Silva N..L. and De Souza W. (1996), Leishmania-induced tyrosine phosphorylation in the host macrophage and its implication to infection. Eur. J. Cell Biol. 71, 206-215.

Martiny A., Meyer-Fernandes J. R., De Souza W. and Vannier-Santos M. A. (1999), Altered tyrosine phosphorylation of ERK1 MAP kinase and other macrophage molecules caused by Leishmania amastigotes. Mol. Biochem. Parasitol. 102, 1-12.

Meyer-Fernandes J. R., Dutra P. M. L., Rodrigues C. O., Saad-Nehme J. and Lopes A. H. C. S. (1997), Mg-dependent ecto-ATPase activity in Leishmania tropica. Arch. Biochem. Biophys. 341, 40-46.

Meyer-Fernandes J. R., Silva-Neto M. A., Santos M., Fernandes E., Vercesi A. E. and Oliveira M. M. (1999), Ecto-phosphatase activities on the cell surface of the amastigote forms of Trypanosoma cruzi. Z. Naturforsch. 54c, 977-984.

Meyer-Fernandes J. R., Lanz-Mendoza H., Gondim K. C., Willott E. and Wells M. A. (2000), Ectonucleotide diphosphohydrolase activities in hemocytes of larval Manduca sexta. Arch. Biochem. Biophys. 382, $152-159$.

Morrison D. C. and Ryan J. L. (1987), Endotoxins and disease mechanisms. Annu Rev. Med. 38, 417-432.

Mukhopadhyay N. K., Shome K., Saha A. K., Hassell J. R. and Glew R. H. (1989), Heparin binds to Leishmania donovani promastigotes and inhibits protein phosphorylation. Biochem J. 264, 517-525.

Ortega-Barria E. and Pereira M. E. A. (1991), A Novel T. cruzi Heparin-binding protein promotes fibroblast adhesion and penetration of engineered bacteria and trypanosomes into mammalian cells. Cell 67, 411-421.

Plesner L. (1995), Ecto-ATPase: Identities and functions. Int. Rev. Cytol. 158, 141-214.

Rocha J. B. T., Wolosker H., Souza D. O. and De Meis L. (1996), Alteration of $\mathrm{Ca}^{2+}$ fluxes in brain microsomes by $\mathrm{K}^{+}$and $\mathrm{Na}^{+}$: modulation by sulfated polysaccharides and trifluoperazine. J. Neurochem. 66 , $772-778$

Rocha J. B. T., Landeira-Fernandez A. M. and De Meis L. (1998), Modification of the $\mathrm{pH}$ dependence of animal and plant transport ATPases by sulfated polysaccharides. Biochem. Biophys. Res. Commun. 244, $720-723$.

Yanagishita M. (1993), Functions of proteoglycans in the extracellular matrix. Acta Pathol. Jpn. 43, 283-293.

Yarlett N. (1988), Polyamine biosynthesis and inhibition in Trichomonas vaginalis. Parasitol. Today 4, 357-360. 